\title{
A Study of Factors Affecting Travel Decision Making of Tourists
}

\author{
Adina Shafi Shaikh ${ }^{1 *}$, Areesha Dars², Keenjhar Memon ${ }^{3}$, Abdul Ghafoor Kazi ${ }^{4}$ \\ 1,2,3,4 Department of Management Sciences, Shaheed Zulfiqar Ali Bhutto Institute of Science and \\ Technology, Hyderabad, Sindh, Pakistan.
}

*Corresponding Author: Adina Shafi Shaikh, Department of Management Sciences, Shaheed Zulfiqar Ali Bhutto Institute of Science and Technology, Hyderabad, Sindh, Pakistan, adinashafi96@gmail.com

\begin{abstract}
Tourism is considered as one of the major sources for creating employment opportunities, generating revenues and supporting culture and entertainment. Travel and tourism plays a vital role by associating themselves with other industries of Pakistan which leads to rise in foreign investment, opportunities of trade, investments in private, local development, and public infrastructure. This study aims to explore the influence of the factors (travel decision making, media, perceived risk, terrorism and safety \& security) tourists' decision making of tourists residing in Pakistan. This is a quantitative study, data was collected from 50 people using questionnaire at 5-point Likert Scale. Data was analysed using descriptive statistics and regression method. The results of this study depict that role of media, safety \& security, and terrorism have significant impact on travel decision making. Within the context of Pakistan terrorism is always a highlighted area on which every tourist think a lot while making a destination choice. Particularly negative media coverage also has significant importance on travel decision making of a tourist. In Pakistani context, this study found that risk perception was supposed more than the actual risk because travel decision to a new place is always riskier somehow, therefore, it has no effect on travel decision making. Tourist develops an insight that what factor is more significant in travel decision making. This study recommends that media, safety and security and terrorism policies are critical for Pakistan to cater the number of tourist by helping them in travel decision making.
\end{abstract}

Keywords: Travel Decision, Pakistan, Safety \& Security, Perceived Risk, Tourist and Terrorism

\section{INTRODUCTION}

One of the fastest developing sectors for the economy worldwide other than technology development is the Tourism Industry (Garg, 2015). Tourism is considered as one of the major sources for creating employment opportunities, generating revenues and supporting culture and entertainment. Travel and tourism plays a vital role by associating themselves with other industries of Pakistan which leads to rise in foreign investment, opportunities of trade, investments in private, local development, and public infrastructure. The country has various tourist destinations i.e. Swat, Malam Jabba, Behrain, Kalam, Shangla, Balakot, Kaghan, Naran, various mountainous ranges, and historical \& archaeological sites.

(i) Copyright (C) 2020 Authors. This is an open access article distributed under the Creative Commons Attribution License, which permits unrestricted use, distribution, and reproduction in any medium, provided the original work is properly cited. 
Pakistan provides diverse opportunities to tourists like trout fishing in the glacial water of Gilgit Baltistan and Swat rivers, Shandur Polo traditional tournament, paragliding, rock climbing, and trekking in northern areas, Jeep and camel safari in the Cholistan desert, Wild Boar hunting, and crabbing in the Arabian Sea. But all these destinations become less attractive and fascinating when it comes to the security of tourists. Few terrorist attacks that were way too highlighted effected the reputation of Pakistan and made almost the whole world scared of visiting Pakistan as it was perceived as a terrorist country. The perception came to an end when the innocent kids of APS were brutally killed in Peshawar on 16th December, 2014. Then the world realized that Pakistani are not terrorist rather they are victims of terrorism. The people of Pakistan are scared to travel from one province to another due to security reasons. Apart from security reason media is also playing vital role which is displaying picture of country as very critical and crucial thus letting people to perceive risk factor way too high. The traveler's behavior towards deciding the destination they would visit will always be tied up with the travel risks (Henderson, 2007). The history shows that 9/11 attacks, and fatal diseases like SARS, swine flu, natural disaster like Tsunami, and terrorist attacks i.e. Bali bombing, 26/11, target killings and various incidents in the last two decades have vacillated the tourism industry due to the crises and disasters. Because of this situation, it created a perception from the traveler's perspective that the need of safety and security become the main factors while choosing a travel destination (Hall, Timothy \& Duval, 2003). The tourism industry should educate or increase the market understanding about the travelers' perception of the safety and security while travelling, also at the same time keep the industry to be stay still in its position or increase in its rapid growth and prevent the unexpected decrease (Henderson, 2007).

Previously, researchers have worked on the topics that only show relationship between the tourism and terrorism, media and terrorism, terrorism and travel decision making, risk and travel behaviour, so we focused to research on "factors affecting travel decision making of tourist". This research will not only help to understand the behaviour of tourist in decision making but it will be also helpful for the future entrepreneurs whose target customer would be tourist to start their new venture in tourism industry. The objectives of this study are,

1. To identify whether terrorism has an influence on travel decision making.

2. To explore how safety and security factor affects travel decision making.

3. To understand the role of media in people's travel decision making.

4. To examine whether perceived risk has an influence on travel decision making.

\section{LITERATURE REVIEW}

\section{TERRORISM}

Definition of Terrorism: Terrorism has been prevailing for a very long time, the words "terrorism" and "to terrorize" first seemed in 1789 during the French Revolution.

\section{REASONS OF INCREASED TERRORIST ACTIVITY}

There are various reasons for terrorism and each one varies from another, religion is considered to be one of the most dominating reasons throughout history. Generally, the terrorist groups couldn't be created without major causes for complaints or dissatisfaction of members of societies (Baker, 2014). For politically weak and excluded people terrorism has become a tool as they feel they are not being taken seriously by the other people. Lack of opportunity for political participation cannot be blamed alone in addition the globalization has caused inequality within the states and countries (Baker, 2014), economic activity and dissatisfaction mainly produced by economic recessions and depression leads to terrorism. History proves that any kind of modernization has given birth to terrorism, such as the world trade centre twin towers in New York (Baker, 2014). 


\section{TOURISM AND TERRORISM}

Being safe on vacation is the first priority of every tourist visiting any destination or city (Baker, 2014). Tourism is that industry from which many undeveloped countries get benefit even more than the developed countries, as it serves the export industry. Many countries have threat from their socioeconomic problems, which mostly leads to rise in crime rates; however terrorism remains the biggest threat (Baker, 2014). Natural and human caused disasters affects tourism up to a certain extent but terrorism affects it more severely. Things common in terrorism and terrorism are more than expected i.e. crossing national border, involving people from different countries (Schlagheck, 1988). In 1972 during the Munich Olympic games the Palestinians attacked Israeli athletes in front of 800 million viewers. All this made people aware of tourism-terrorism relationship throughout the world (Korstanje, 2010).

\section{THE IMPACT OF TERRORISM ON TOURISM PLACES}

According to (Arana \& Leon, 2008) "tourism is that industry whose demand and supply are immune to events like terrorism or political violence". Many studies show the impact of terrorism on tourism. Ender and Sandler (2006) found negative impact of terrorism on tourism revenues in European countries and proved that destinations were substituted by tourists in order to minimize risk of terror attack (Arana and Leon, 2008). There is another study that focuses on the event or frequency of larger impact on tourism demand. Seddighi et al,(2001) and Stafford et al (2002) political instability is caused by terrorist attacks, which leads to downfall of tourist arrivals or some destinations (Baker,2014). This study aims to explore that all the terrorist activities takes place on crowded and attractive tourism places and to what extend people feel safe in the country they live in (in terms of terrorist activity). Lastly this study examines whether a tourist will travel to a destination which was targeted for a terrorist attack.

\section{Travel Decision Making}

The exploration of information and travel decision for a traveller is a difficult experience. It is a difficult experience because there is a great volume of data available and tourists often join different bits of it. The decisions of travelling of tourists are not based on one single choice (such as destination, accommodation or travel companions), but rather it is a complicated decision with many alternatives around. The push factors in the travel decision making of tourists depend on the attributes of a destination (Cohen et al., 2014). Dellaert et al., (2014) concluded that, whenever the travellers face a problem regarding their travel decision, they tend to construct a list of alternatives in their minds. Consequently, they identify the key factors which have an influence and play a major role in their travel decision process. As stated by (Gartner, 1994), the information available on different sources results in destination choice decision of a tourist. (Amara, 2012) also concluded that if travellers want to change their destination choices, modify their travel behaviour etc. they always check out the data or information that is accessible to them. Many of the tourists often make images towards multiple tourist destinations based on the information that is available to them. To reduce uncertainty, most of the tourists rely on the experiences of others so that they do not face any problems while making their travel decision (Kotler, Bowen, \&Makens, 2013). This study explores that how often people travel within Pakistan and for what purposes e.g. Business, Leisure, Educational, etc. Additionally, it also looks into the travel information search tool which was used by the travellers.

$\mathrm{H} 1$ : Terrorism is a barrier to tourist while making a travel decision making. 


\section{SAFETY AND SECURITY}

Tourists consider the safety and security and privacy while choosing a destination (Alananzeh, 2016). The study of (Nejati and Mohamed, 2015) observed three major aspects of a destination, which are the "quality", "uniqueness" as well as "distance and value" that influence the travel decisions of international tourists. Understanding the motives and profiles of tourists is important in realizing what influences their holiday selection, in the present case Pakistan, and to what extent tourists from various backgrounds are influenced by safety and security (Min, Martin, \& Jung, 2013). This study explores the needs and concerns of people about their security. Furthermore, it also looks into the level of involvement of government towards the investment in the security of the country. And it helps to explore whether the people are satisfied with the government's anti-terrorist strategies or not.

$\mathrm{H} 2$ : Safety and security influences travel decision making.

\section{ROLE OF MEDIA}

Individuals can speak and connect with one another internationally after the emergence of social media (Kelly, 2016). Consumers are able to progressively manipulate different shoppers with their own viewpoints and experiences as social media has become more expressive. As social media is cheap and bias-free, it shows an edge for promoting communications (Kotler, P, Kartajaya,H., Setiawan,I., 2010). The decisions and judgments of individuals regarding their travelling behaviour have changed because of social media. Additionally, social media has also influenced the tourism industry in terms of however individuals will access and use data. Tourism industry has become a strongly informative industry as nowadays tourists enthusiastically generate, consume, and share out different content (Narangajavana, 2017). Likewise (Kelly, 2016) described that "Over eight out of ten (85\%) travellers worldwide claim that people's comments; videos and photographs on social media influence their plans." To conclude, the way individuals explore and buy different things, not only products but services too, are influenced by the search they do on the internet. Decisions concerning to tourism like, where to travel, what is the best time to travel, where to eat etc., all of the information available on the internet influence the travel decision making of tourists. This study explores the impact of negative media coverage on the travel decision making of tourist. In addition, it will also identify the power media has to build up the image of a tourist place and the role of media in portraying the tourists place in a positive manner.

$\mathrm{H} 3$ : Role of Media has an impact on the travel decision making.

\section{Perceived Risk}

Generally, the term risk means threat of damage, injury, loss or any other negative occurrence that is caused by either external or internal weakness and it can counter balanced through planned actions (Business Dictionary.com). In tourism, uncertainty and consequences function as risk perception (Moutinho, 2000) that the some consequences are more wanted by the tourists than others. Although the risk may entail positive and negative outcomes, it is often studied as undesirable outcomes, such as loss of time or money, which may arise from consuming tourism products. The messages delivered by tourist companies through the marketing and media communication affects the risk perception and the level of risk that tourists are generally willing to take is also significantly influenced by some factors which are their personality and socio-cultural background (Konferenciakalauz, 2009). Having first been introduced by Bauer in 1960, the concept of perceived risks has since become one of the important elements in the context of consumer behaviour. Perceived risk has been remarked as a core concept that influences tourists' holiday decision making (Sharifpour et al., 2014). In hospitality and tourism, risk can be referred to as the loss being experienced by the tourist during the purchasing and consuming travelling services and at the destination (Placeholder1)), risk perception effects on tourists' decision making (Garg, 
2015) This indicated that different consumers perceived risks differently in various products and services. The way the media release the article about one particular destination can be the most influential factors for decision making because it could generate the whole region to be perceived as risky. This study aims to explore whether the perceived risk in Pakistan is higher than the actual risk. Additionally, the main reason is to identify that the perceived risk is the extension of the topic of political violence and lastly to check the level of risk has an impact on a tourist in choosing a tourist destination.

H4: Perceived risk influences travel decision making.

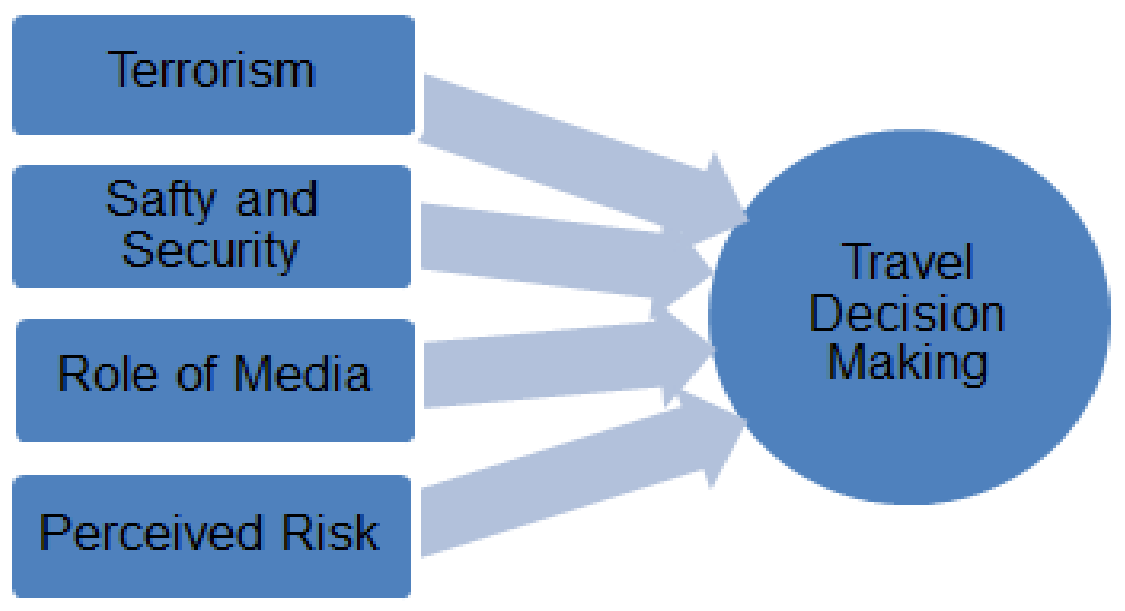

Fig. 1: Research Model

\section{METHODOLOGY}

\section{RESEARCh DESIGN}

This study examines the factors which influence people's behaviour and perceptions towards their travel decision making. Further, it explores to what extent characteristics such as the role of media, terrorism, risk perception and safety have an impact on their travel decision making. So for this study, we have used explanatory research design.

\section{TYPE OF RESEARCH}

The study is going to find the influence of factors on the travel decision making of a person by using terrorism, safety, perceived risk, and media as independent variables so the type of this research is "quantitative research".

\section{RESEARCH APPROACH}

In this study, the deductive approach is used as we intend to test the belief concerning travel factors and tourists. Furthermore, in view of the study of the current sources we have built up hypotheses and we expect to test the hypotheses through essential information gathered from the respondents.

\section{Population AND SAMPLe Size}

In this study, the sampling population is the general public and tourists of Pakistan. The sample size of the study was determined by using (Roscoe, 1975) rule of thumb as it is one of the most acceptable way of determining sample size. It refers as number of variables into 10 and it should be between 
minimum 30 to maximum 500. As per rule sample size of 50 people who have great information and are more into the tourism industry of Pakistan were chosen. The non-probability sampling method was chosen as we needed the participants who have information about the tourism and factors that influence their travel decision making. The convenience sampling method was chosen because it was convenient for the individuals who want to be the part of the survey questionnaire.

\section{Data Collection Tool}

The study was carried and created online with the poll by Google docs, which ensures obscurity to whoever participates. The survey was just accessible in English and basically set up with 5-Point Likertscale questions. In the initial segment of the questionnaire, respondents needed to give individual information about them, for example, age, sexual orientation, and so forth. Furthermore, in the second piece of the survey respondents needed to address questions identifying with their travel behaviour, risk perceptions and their perception of the impact of media coverage.

Table 1: Data Collection Tool - Variables, Number of Items, and Sources

\begin{tabular}{llll}
\hline Section & Variable & \# of Items & Source \\
\hline 1. & Travel Decision & 3 & (Welledits, 2016) \\
2. & Safety \& Security & 3 & \\
3. & Terrorism & 3 & \\
4. & Perceived Risk & 3 & (Raithatha, 2017) \\
5. & Media & 3 & \\
\hline
\end{tabular}

\section{DATA ANALYSIS}

The information gathered from the survey have been analyzed through SPSS(statistical package for social sciences) in which multiple regression and correlation between variables were performed to analyze the information, depict the relationship among variables to get statistical and factual information.

\section{Descriptive Statistics}

In this study the percentage of respondents were $66 \%$ females, $32 \%$ males, and $2 \%$ transgender. Percentage wise categories of respondents' age $72 \%$ (18-24 years), 20\% (25-34 years), and 8\% (35-40 years). $22 \%$ were self-employed, $10 \%$ are public servants, and $16 \%$ worked in the private sector whereas $52 \%$ of the respondents fall in the others category. The $52 \%$ respondents travel once every year, $34 \%$ travels once every few months, and $14 \%$ travel once every month within Pakistan.In response of the general purpose of visit, $78 \%$ travel for leisure and adventure, $14 \%$ travel for business, and $8 \%$ travel for educational purpose. For the travel information search tool, $22 \%$ of respondents prefer to take guidance from particular travel associations which is the third most result, 44\% take advantage from internet and the $30 \%$ travel on the basis of their friend's recommendation, $2 \%$ from magazine and $2 \%$ from advertisement.

\section{RELIABILITY ANALYSIS}

In data analysis, the Cronbach's alpha is a measure of internal consistency, that is, how closely related a set of items are as a group. A reliability coefficient of 0.70 or higher is considered "acceptable" in most social science research situations. In this study the alpha coefficient for the fifteen items is 0.752 , therefore, the items have acceptable internal consistency. 


\section{CORRELATION ANALYSIS}

Correlation analysis demonstrates a connection between at least two variables and shows whether there is any change in one variable given that there is a change in another variable. In this study, the dependent variable is travel decision making and independent variables are terrorism, perceived risk, safety, and media. Pearson's correlation coefficient between safety and security and travel decision making is 0.591 or $59.1 \%$ which infers that there is a moderate positive relationship among safety and travel decision making. Besides, Pearson's correlation coefficient among terrorism and travel decision making is 0.576 or $57.6 \%$ which likewise suggests that there is a moderate positive relationship among terrorism and travel decision making. In addition, Pearson's correlation coefficient between perceived risk and travel decision making is 0.564 or $56.4 \%$ which demonstrates that there is a moderate positive relationship between perceived risk and travel decision making. In conclusion, Pearson's correlation coefficient between media inclusion and travel decision making is 0.684 or $68.4 \%$ which demonstrates that there is a moderate positive relationship between media coverage and travel decision making. Table 2 show that relationships among variables are statistically significant.

Table 2: Correlation Analysis

\begin{tabular}{llllll}
\hline & $\begin{array}{l}\text { Travel Decision } \\
\text { Making }\end{array}$ & $\begin{array}{l}\text { Safety and } \\
\text { Security }\end{array}$ & $\begin{array}{l}\text { Terrorism } \\
\text { Perceived } \\
\text { Risk }\end{array}$ & Media \\
\hline Travel Decision Making & 1 & & & \\
Safety and Security & $.591^{* *}$ & 1 & 1 & \\
Terrorism & $.576^{* *}$ & $.418^{* *}$ & $.337^{*}$ & 1 & $.583^{* *}$ \\
Perceived Risk & $.564^{* *}$ & .245 & .228 & 1 \\
Media & $.684^{* *}$ & .142 & ${ }^{* *}$. Correlation is significant at the 0.01 level (2-tailed).
\end{tabular}

\section{REgRESSION ANALYSIS}

In spite of the fact that the correlation analysis indicates whether there is a change in one variable because of change in another and it additionally demonstrates the strength of relationship yet it needs to check the effect of independent factors on the dependent variable. The regression analysis indicates how much change in the dependent variable may happen because of a unit change in the independent variable. Table 3 demonstrates the variable entered and variables expelled. Every one of the variables was entered at the same time and no variable was expelled. The strategy utilized was "enter method" which demonstrates the type of multiple regression i.e. standard.

Table 3: Variables Entered/Removed

\begin{tabular}{llll}
\hline Model & Variables Entered & Variables Removed & Method \\
\hline 1 & Media, Safety and Security, Terrorism, Perceived Risk &. & Enter \\
\hline & a. Dependent Variable: Travel Decision Making & b. All requested variables entered.
\end{tabular}

Table 4 model summary mentions R, R-square, and adjusted R-square. As per the outcomes, the 0.784 variance in travel decision making is because of the changes of these four predictors' terrorism, safety, perceived risk, and media coverage. $\mathrm{R}$ is 0.885 which demonstrates the connection between travel decision making and other four indicators is moderate which implies the shared variance is a fit model.

Table 4: Model Summary

\begin{tabular}{|c|c|c|c|c|c|c|c|c|c|}
\hline \multirow[b]{2}{*}{ Model } & \multirow[b]{2}{*}{$\mathbf{R}$} & \multirow[b]{2}{*}{$\begin{array}{l}\text { R } \\
\text { Square }\end{array}$} & \multirow[b]{2}{*}{$\begin{array}{l}\text { Adjusted R } \\
\text { Square }\end{array}$} & \multirow[b]{2}{*}{$\begin{array}{l}\text { Std. Error of } \\
\text { the Estimate }\end{array}$} & \multicolumn{5}{|c|}{ Change Statistics } \\
\hline & & & & & $\begin{array}{l}\text { R Square } \\
\text { Change }\end{array}$ & $\begin{array}{l}\text { F } \\
\text { Change }\end{array}$ & df1 & df2 & $\begin{array}{l}\text { Sig. F } \\
\text { Change }\end{array}$ \\
\hline 1 & $.885 a$ & .784 & .764 & .30469 & .784 & 40.748 & 4 & 45 & .000 \\
\hline
\end{tabular}

a. Predictors: (Constant), Media, Safety and Security, Terrorism, Perceived Risk

b. Dependent Variable: Travel Decision Making 
Table 5 shows that Terrorism accounts for 0.271 changes in travel decision making and its t-value and $\mathrm{p}$-value are 3.422 and 0.001 respectively. Leads to the results that hypothesis $\mathrm{H} 1$ : Terrorism is a barrier to tourist while making a decision is accepted.

As shown in Table 5, standardized Beta of safety and security is .385, indicating moderate contribution in explaining the variation in travel decision making. and the t-value and significance ( $p$ value) which is 5.005 and 0.000 respectively; this $p$-value is less than 0.05 leads to the result that hypothesis H2: Safety and security influences travel decision making is accepted.

Table 5 shows that the media coverage accounts for 0.525 changes in travel decision making and its $\mathrm{t}$-value is 6.151 and $\mathrm{p}$-value is $\mathbf{0 . 0 0 0}$. These values lead to the result of that hypothesis H3: Role of media has an impact on the decision making of tourist is accepted.

Table 5 shows that there is a variation in the value of travel decision making due to perceived risk i.e. 0.072 . And the $t$-value and $p$-value are 0.813 and 0.420 which is more than 0.05 . Hence leads to the result that hypothesis $\mathrm{H} 4$ : Perceived risk influences travel decision making is rejected.

Table 5: Hypotheses Testing

\begin{tabular}{lllll}
\hline \multirow{2}{*}{ Model } & \multicolumn{2}{l}{ Standardized Coefficients } & \multirow{2}{*}{ Sig. } \\
\cline { 3 - 4 } & Beta & -1.256 & .216 \\
\cline { 3 - 4 } 1 & & .271 & 3.422 & .001 \\
& Terrorism & .385 & 5.005 & .000 \\
& Safety and Security & .525 & 6.151 & .000 \\
& Media & .072 & .813 & .420 \\
\hline
\end{tabular}

a. Dependent Variable: Travel Decision Making

\section{CONCLUSION}

In light of the outcomes highlighted in the previous section, the following conclusions are drawn: safety and security have a moderate positive significant relationship with travel decision making. Terrorism likewise has a moderate positive significant relationship with travel decision making. While perceived risk also has a moderate positive but insignificant impact on travel decision making. Media coverage has a moderate positive and significant impact on travel decision making. According to the findings, safety and security and media coverage have a high contribution in explaining the variation in travel decision making. i.e. 0.385 and 0.525 respectively and the other two variables do not have a major contribution.

The first hypothesis of the study was to check the impact of terrorism over travel decision making. According to the study, the results proved that it has a great impact which proved by positive significance according to the results of this study. Terrorism prevailing in the country tends to haunt the country which ultimately affects the tourism industry and hence weaken the decision.

The second hypothesis of this study was to examine the relationship between safety and travel decision making of tourists in Pakistan. So, the result shows that there is a moderate positive significant relationship between safety and travel decision making which seems justifiable because safety and security play a vital role in impacting the decision, every tourist always highlight security issue before choosing the destination because tourist wants peace and calm environment in order to energize them.

The third hypothesis of this study was to look at the relationship between media and travel decision making. As per the outcomes, there is a positive significant relationship between media coverage and travel decision making. This implies media affects travel decision making and plays a major role in portraying the negative or positive image of a country with respect to the travel industry since individuals believe on the news given by media and settle on their choices as indicated by it. Along these lines, the media is unquestionably in charge of promoting or demoralizing the nation's image. 
The fourth hypothesis for the study was to explore the impact of perceived risk on travel decision making. According to the results generated it is insignificant and hence rejected. This depicted that the destination is always riskier when a person travels to a new destination.

As it is known that the tourist industry has a significant portion in the development of the economy and can be a major contributor GDP (gross domestic product). If the tourist industry performs efficiently, the economy will tend to increase and flourish. In order to increase the performance, this research project explored the factors affecting tourist in travel decision making which are highly responsible for travel decision of a tourist residing in Pakistan in order to come up with a concrete result that what factor is hindering a tourist while making a travel decision.

The study overall depicts justifiable results because Pakistan is a developing country and there are a lot of rooms still for improvement though government is working on many factors like security and terrorism but its implementation is still recommended to be more strong. There is still a dire need for more investment in anti-terrorist activities so foremost strategy for Pakistan is to increase security measures to recover the tourist confidence.

The regulatory authorities should instruct the municipals of tourist places to follow the strict codes of safety security by making its implication stronger Secondly media agencies should be restricted to air the content which is highly affecting the image of the destination instead media should promote Pakistan as safe and attractive tourism

\section{FUTURE DIRECTION}

Further research can be done by taking other factors which can affect travel decision making such as climate, income, political stability. Industry other than tourist industry could also be taken as a sample of the study. Geographical location apart from Hyderabad could be chosen.

\section{Reference:}

Alananzeh. (2016). Impact of Safety Issues and Hygiene perceptions on customer satisfaction , 45-48.

Amara, D. (2012). Tourists' risk aversion and willingness to take risks: the case of tourists visiting Egypt after 25th January revolution.

Arana, J. L. (2008). the impact of terrorism on tourism demand. Annals of Tourism Research , 299-315.

Baker, D.M.A. (2014). the effects of terrorism on the travel and tourism industry. international journal of religios and pilgrimage, 9.

Cohen, S. A., Prayag, G., and Moital, M. . (2014). Consumer behaviour in tourism: Concepts, influences, and opportunities. Current Issues in Tourism, Vol. 17 , 872-909.

Dellaert, B.G.C., Arentze, T.A. and Horeni, O. . (2014). Tourists' mental representations of complex travel decision problems . Journal of Travel Research, Vol. 53 , 3-11.

Enders, W. and sandler, T. (2006). Distribution of Transational Terrorism among Countries by Income Class and Geography after 9/11. International Studies Quarterly , 367-393.

Garg. (2015). Travel Risks v/s Tourist decision: Making a Tourist perspective , 52.

Garg, A. (2009). Crisis in Hospitality and Tourism: A study on the impacts of terrorism on Indian Hospitality and Tourism Industry. M M University Journal of Management Practices, Vol.3 (1\&2), 1-12.

Gartner, W. C. (1994). Image formation process. Journal of Travel and Tourism Marketing , 191-215.

Hall C.M., Timothy D.J. \& Duval D.J. . (2003). Safety \& Security in Tourism: Relationships, Management and Marketing. . New York: Haworth Hospitality Press .

Henderson, J. (2007). Tourism Crises- Causes, Consequences and Management. USA: butterworthHeinemann .

Kelly, J. (2016). Volumtourism Worldwide.

Konferenciakalauz.hu. (2009). Socio Demographic constraints to travel behaviour. 
Korstanje, M. (2010). September 11 and perception risk theory. Pasos, revista de turimso y Patrimonio Cultural , 8(2), 389-402.

Kotler, P. R., Bowen, J. T., \& Makens, J. . (2013). Marketing for Hospitality and Tourism (6th ed.). Prentice Hall.

Kotler, P., Kartajaya, H., Setiawan, I., . (2010). Marketing 3.0. John Wiley \& Sons, Inc, New Jersey , 8-9.

Min, K. S., Martin, D., \& Jung, J. M. (2013). Designing advertising campaigns for destinations with mixed images: Using visitor campaign goal messages to motivate visitors. Business research , 66(6), 759-764.

Moutinho, J. (2000). Strategic management in tourism. Wallingford: CABI Publishing. 7.

Narangajavana, Y., Callarisa Fiol, L. J., Moliner Tena, M. Á., Rodríguez Artola, R. M., \& Sánchez García, J. (2017). The influence of social media in creating expectations. An empirical study for a tourist destination. Annals Of Tourism Research , 6560-70.

Nejati and Mohamed,. (2015). Investigating the key factors influencing the traveldecisions of International Tourist, 31-33.

Raithatha, Y. (2017). Understanding the economic impact terrorism has on the destination decision making: Northern Irish tourists (Doctoral dissertation, Dublin Business School).

Roscoe, J. T. (1975). Fundamental research statistics for the behavioral sciences.

Schlagheck, D. M. (1988). International Terrorism. Lexington MA: Lexington Books

Seddighi, M.W. Nuttall, A.L. Theocharous H.R. (2001). Does cultural background of tourists influence the destination choice? An empirical study with special reference to political instability. Tourism management, 22(2), pp. 181-191

Sharifpour et al. (2014). Tourist experience of a place. 11-13.

Stafford, G., Yu, L., \& Armoo, A. K. (2002). Crisis management and recovery: How Washington D.C. hotels responded to terrorism. Cornell Hotel \& Restaurant Administration Quarterly. 43, 27-40.

Welledits, V. (2016). People's Perceptions and Behavior towards Destinations that have been affected by Terrorism. Unpublished Bachelors Thesis, Modul University Vienna, Austria. 